\title{
Representation of Cultural Ambivalence in Eliza Hamilton's Translation of the Letters of A Hindoo Rajah ${ }^{1}$
}

\section{Prakash Paudel}

\begin{abstract}
Eliza Hamilton in her two-volume epistolary novel Translation of The Letters of A Hindoo Rajah (1819), by projecting two characters who undergo the oppositional experiences during their contact with English people, creates an ambivalent situation which neither represents England as totally positive nor India as completely negative. The two perspectives of Zaarmilla and Sheermaal exclude one another's rendering. To unpack this contradictory narrative position, the concept of acculturation and cultural stress, especially formulated by John W. Berry is taken in interlocution. By rendering these two sorts of antithetical narratives juxtaposed together confirms the dynamics of ambivalence which does not regard Saidaian notion of Orientalism intact.
\end{abstract}

Key words: Acculturation, ambivalence, contact, representation

The late eighteenth century epistolary novel, The Translation of the Letters of a Hindoo Rajah (1796) by Eliza Hamilton, presents a western view on an eastern citizen's look at the western values. The volumes contain eighteen letters altogether. The first volume contains eleven letters, whereas the second volume contains seven letters. These letters are written by three different persons: Zarmilla, the king of Almora, a state of the then India, Maandaara, the Zimeendar of Cumlore, and Shreemal, the Brahmin. The time setting of the novel is the late eighteenth century. It was the time when the British people had been in India. The novel is full of the narratives from the people of the eastern part of the world. The narrators are no other than the Hindu people who possess different perspectives towards the growing influence of England and the culture of English people.

\footnotetext{
${ }^{1}$ Cite this article as: Paudel, P. (2021). Contemporary Research: An Interdisciplinary Academic Journal, vol. 5 (1) DOI: https://doi.org/10.3126/craiaj.v5i1.40488

Prakash Paudel, Assistant Lecturer, Nepal Open University; Email: prpaudel2004@gmail.com

Article history: Received on August 30; Accepted on October 2; Published on October 21

Peer reviewed under the authority of CRAIAJ, academic journal of Ghodaghodi Multiple Campus, Kailali, Nepal, with ISSN 2717-4611 (Print) and ISSN 2717-462X (Online).

(C) 2021 CRAIAJ
}

Full text of this article can be downloaded from www.craiaj.com and www.nepjol.info 
The letters exchanged among these three persons show how these three different persons look at the same thing from different perspectives. When the cultures from the two different geographical part come across, they certainly affect upon the people who live or travel in both territories. This sort of situation leads either to reject other's culture or to accept or do both of them simultaneously. In most of the situations, people accept the changes brought by the influence of other culture, not abandoning their own culture. The Hindoo Rajah of Alomra is influenced by the English culture as his travelogue unfolds.

While projecting the eastern character in the western world, the novelist has adopted a special technique. The letters exchanged among the characters provide the enough background to know each character's attitudes regarding the eastern as well as western culture. The writer is English. The representation of two cultures is not biased but is ambivalent since she highlights both cultures, unlike most of the European writers. Said (2003), in Orientalism, argues that the European writers often project the characters from eastern world irrational and emotional (p. 58). But the characters in the novel are not depicted in such line. Hence, this research looks at that part of representation.

Written from the perspective of Indian Hindus of the eighteenth century, the novel projects the strict Hindu values and practices of the then society. The first volume highlights various opinions regarding the culture of English people. The conservative Hindus strictly adhere to the Hindu rules and regulations. Similarly, the second volume is all about the experiences of the Hindu Raja, who had been to England. The novel, thus, is the projection of the western culture from the eye of a Hindu Raja. By incorporating the letters of a Hindu Brahmin, it allows the readers to find the world from the strict Hindu eyes. The letters are in the dialogic form; they interact with each other.

Though the novel was published during the hay day of colonization, 1796 AD, it did not get much critical attention well. Written during the time of romanticism in England, the novel is mostly read from the concept of romanticism. Hinging onto the romantic theme, Anne K. Mellor, in “Romantic Orientialism Begins at Home: Elizabeth Hamilton's (1811) Translations of The Letters of a Hindoo Rajah”, states:

Eliza Hamilton's subtle and nuanced analysis of the intersection of Hindu and British culture published in 1796 is the core text of our understanding of Romantic orientalism. It is based on an extensive familiarity with Hindu law, literature 
religious practice and politics, which Hamilton gained from her brother Charles, a semi-taught and passionate orientalist.... (p. 151)

During the time of romanticism, the nature is valorized. Orientalism is all about depicting the eastern world, thus Romantic orientalism concerns on the depiction of the eastern world from the western eyes. Hamilton as the writer explores that orientalist features especially the Hindu law and literature. Eastern religious practices are also depicted in the narrative. Hamilton got all those ideas of Indian culture and religious practices from her brother who had been to India and had interest in the Indian culture. Hence, this novel's narrative is all about depicting the Indian culture.

Unlike reviewing the novel from romantic perspective, some critics have inquired the philosophical foundation of the novel. The tone of the novel is satirical as the novel presents the Western world from an innocent person. Being in the new place of different culture, the king pays heed to the parts of the culture, which are ignored and sometimes he points to the events that even mock the whole cultural foundations. Critiquing the philosophical nature of the novel, Fiona Price (2002), in "Democratizing Taste: Scottish Common-Sense Philosophy and Elizabeth Hamilton”, avers:

This satiric critique of Eastern and Western values contained a lengthy parody of 'Philosophers[s]', who, instead of being men “"deep in knowledge either moral or natural”, were ignorant individuals, 'entertain[ing] a high idea of their own superiority, from having the temerity to reject whatever has the sanction of experience, and common sense'. (p. 184)

No doubt the novel makes parodies of the philosophers, who make an evaluation of the values of other's cultures without deep and serious understanding. By giving voice to Zaarmilla, who lacks a complete understanding of the western culture, Hamilton makes fun of such philosophers. The narrative of Shreemaal undercuts his understanding and representation, even of his own culture.

Moreover, Tara Ghoshal Wallace (1952), in Imperial Characters: Home and Periphery in Eighteenth-century Literature, reading the novel from feminist perspective, finds that, through Zaarmilla's depiction, Indian women fail to be superficial. The women of England are represented more superficial. The best example is madam Dewan. She puts: 
"In Zaarmilla, Hamilton embodies her ideas of (and hopes for) enlightened Hinduism, although it must be noted that Indian women, like the natives of America in Hermsprong, fail to provide an alternative to superficial and conventional British women" (p. 118). The candid character Zaarmilla is the king of a Hindu state who gets chance to visit England with the help of an English friend. Hamilton projects her notions from the mouth of the king. He is critical of the status of the women. He makes a comparative study of female positions in England and India. He believes that the education provided in England is the ground that shapes the women's status. This sort of educational background is lacking in India, he believes. However, the superficiality of the English women is noteworthy. He gets into the company of Miss Dewan and Miss Ardent. The superficiality like that of Miss Dewan is not common in India. Her character sounds really different from that of an Indian woman.

Unlikely, another critic Susan B. Egenolf (1988), in The Art of Political Fiction in Hamilton, Edgeworth, and Owenson, argues that the position of Eliza Hamilton in the novel is like that of other learned persons of the Asiatic Society. She evaluates in a neutral vein showing the drawbacks of both cultures - the Indian culture and European culture. This sketch has benefited the British rulers of the then India. Susan observes Hamilton's position as:

Her central narrative, purporting to be a translation of a collection of letters written by and to Hamilton's hero Zaarmilla, Rajah of Almora, critiques both British and Indian culture, as many critics have suggested. In choosing to write an epistolary novel concerning India, embellished with a learned "Preliminary Dissertation" and extensive footnotes, Hamilton made several ideological choices that place her firmly in the company of the accomplished men of letters... who translated Oriental culture for the British. (p. 18)

The novel posits a critical lens on the both cultures, English and Indian. The presentation of the character Zaarmilla, from the letters he writes to his friends, she makes a sharp evaluation of Hindu culture. His connection with the European culture provides ample background to be critical of both. Moreover, his friends present the dark side of the English culture which makes a narrative full of critical evaluation of both cultures. 
Edward W. Said's Orientalism argues that each literary production of the West creates a binary and represents the non-west as barbaric, uncivilized and irrational. His description takes the unidirectional line. He has underestimated the dynamics of each writing. Beerendra Pandey (2009), a literary critic, puts:

Said is indeed entitled to pinpoint the massive negative representations about the East, but these representations are not invariable and incontrovertible, for literary texts are dynamic and vibrant, often embracing a number of views at odds with each other including the possibility that orientalist or counter-orientalist opinion can have a co-existence with in a literary text. (p. 246)

A work of art especially a literary text cannot be unidirectional and lop sided. It may contain more than one way of representation. The generalized and monolithic affirmation may not always be functional since each writing stands on its dynamics of multifaceted representations, which might be ambivalent as well. In the case of Hamilton's epistolary novel, the process of acculturation exhibits the prevalent ambivalence, which undercuts Saidian notion of essentializing the representation.

Acculturation is a "social process" in which a person, by acquiring "language, values and norms through imitation, practice and experimentation" enables to be a member of a culture (Barker, 2002, p. 221). Standing near to Barker, John W. Berry, in "Acculturation: living successfully in two cultures", puts acculturation as "a result of that contact between two or more cultural groups and their individual members" (p. 698). The result of that contact is the changes on the part of both regarding their behaviour, attitudes and activities. David L. Sam (2006), in "Acculturation: Conceptual background and core concepts", making a distinction between individual and group level changes, shares that at the individual level, it is in the aspects of "identity, values, attitudes and behaviour" (p. 14). But at the level of the group "the changes might be in the social structure of the group, the economic base or the group's political organization" (p. 14). The process of acculturation runs in two ways. Berry puts it as "mutual" and "reciprocal" acculturation. Mutual acculturation engages one into assimilation process whereas reciprocal one resists assimilation. In Translation of The Letters of A Hindoo Rajah, Zaarmilla, the king of Almora, because of the companionship of the Capatin Percy, projects the British culture in particular and Christian culture in general better than his own culture, whereas Sheermaal, the Brahmin, thinks opposite. 
The first volume, as the letters exchanged among Zaarmilla, his friend Maandaara and Sheermaal, exposes their views. These all narratives are the depiction of the west by the eastern people who are Hindus. The backdrop of political instability and the arrival of British people in India provides an ample condition for the Hindu people to come in contact with British people who follow Christian religion, more than the influence of the Muslim people and Mogul emperors. Zaarmilla and Sheermaal are no more exceptions. Regarding the case of Zaarmilla, who is with the captain Percy, after reading the Sasters, formulates and furnishes his concepts regarding Christians, especially the British people and their way of living. Likewise, Sheermaal develops his ideas about British people after his voyage and England stay. In the second volume, Hamilton puts the letters of Zaarmilla in sequence, written from England, to Maandaara. During his stay there, he comes in contact with British people, their culture and their pattern of living. The opinion of Zaarmilla is juxtaposed to the experiences of Sheermaal in an ironic contrast which takes place as a part of acculturation process.

The process of acculturation begins as the king of Almora, Zaarmilla and Captain Percy meet and "from that moment [their] hearts were united by the seal of friendship" (Vol. I, p. 9). Captain Percy's behaviour influences the king heavily.

His conversation was like the soft dew of the morning, when it falls upon the valley of roses; at once refreshed and purified the soul. His knowledge in comparison of that of the most learned among pundits of the present age, was like the mountains of Cummon compared to the nest of an ant. (Vol. I, p. 9)

Though on the surface level this remark sounds a comment on an individual's behaviour and attitude of a person, Captain Percy, but, by extension, it builds a positive impression of the Britishers which, in Zaarmills's narrative, continues throughout his letters.

"Benevolent people of England" who follow the shaster, in the line of Zaarmilla, go in the various parts of the world "to enlighten and instruct" (Vol. I, p. 18). King Zaarmilla accepts that because of "the indulgences of [his] English friend, [he] was favoured with the perusal of the Christian Shaster" (Vol. I, p. 16). David L. Sam (2006) writes "a major prerequisite for acculturation is contact following a meeting between at least two cultural groups or individuals who come together in a 'continuous' and 'first hand' manner" (p. 14). The meeting between Captain Percy and acknowledging shasters by 
Zaarmilla are 'the first hand' and 'continuous' experiences that create a contact zone like a vantage point enough to reflect back upon oneself. The more Zaarmilla remains in the company of Captain Percy, the more he acquires knowledge about the west and gets sufficient background for succinct reflection.

Moreover, the sojourn of Zaarmilla to England after Percy's request familiarizes him to the British culture of the "honest people" (Vol. II, p. 39). "The piety, learning and morality of men is only to be equaled be their humility" of "happy country, where the prudence and fidelity of women are of high rank" (Vol. II, p. 21). Before the visit, the continuous rapport between Captain Percy and Zaarmilla has provided a platform to speculate the condition of British women. The Christian shaster that provide him "the grandeur of sublimity and the simplicity of truth" make him clear that "women are considered in the light of rational beings! free agents"(Vol. I, p. 25). At the very time realizing the women's better position in England after reading the shaster, he accepts socially negotiated role of women in Hindu society, which is much limited and within the condensed boundaries. This depicts the part of realization and evaluation on his side. Realizing the cultural limits of one's culture is the part of acculturation process.

Despite the "honourable" religion and "favourable" virtue of English people, the king experiences some lack among the British people in his virtually imagined frame of reference. "[T]hus everything is produced with a companion which shall destroy it", Zaarmilla sums up (Vol. II, p. 21). That is to say, the vice is always with virtue. Saying this Zaarmilla appropriates the predominant virtues and less vice in his opinion. The ideal perception of the British women by Zaarmilla fails as he meets the widow, Miss Dewan, for him, who needs to go to the boarding school and develop her manner.

After much reflection I think I can trace the unenlightened state of this woman's understanding to her want of instructions. Had she received her education at one of those wise, learned and pious seminaries, called boarding schools, her mind would no doubt have been vigilantly defended from the noxious breath of vanity and conceit. (Vol. II, p. 32)

The "haughty", "arrogant" and "disdainful lady", the wife of Dewan, is beautiful but does not suit according to the British norm and value of a woman. Her "extravagance" and "fantastic finery", for him, does not fit into the general behaviour of a normal woman of 
England. At the same time, Zarmilla is implicitly hinting towards the much importance of the British schooling system, which could have changed her behaviour. While saying so, he apprises and validates the British system of education that lacks in India. But just in juxtaposition, Zaarmilla draws on the character of Lady Ardent who epitomizes his ideal perception of a British woman despite the fact that he comes to know all the women of England do not go in the same parameter. Miss Ardent, for him, possesses a "decisive manner" which has made "her qualified to become the Vizir of an Empire" (Vol. II, p. 121).

He, further, observes the English people as mean, greedy and reluctant; qualities that contradict Christian values. This ironical and paradoxical condition that Zaarmilla experiences makes him aware. Rethinking starts and he evaluates the prior formulation of English people's imagined high esteemed moral and social countenance. This brings changes in an attitude of the person. It is more psychological. John W. Berry (2005) puts "cross-cultural psychology views individual human behaviour as interacting with the cultural context within which it occurs" (p. 701). That is to say, an individual's encounter with the other culture brings changes in that individual, especially in one's behaviour, which is mostly determined by individual psychology. Regarding the case of Zaarmilla, the changes in his attitude and reception are traceable.

Unlike the very reckoning of Zaarmilla, the narratives of Sheermaal's experience in England take the "reactive" path which "rejects the cultural influence" as Berry puts, "changing back towards a more 'traditional' way of life, rather than inevitably towards greater similarity" (p. 701). Drawing out the very naked and cruel picture of British social life, Sheermaal, ironically enough to Zaarmilla's idealization, disfavours it, which propels him near to his own tradition, eulogizing it.

In the stark opposition to Zaarmilla's description of benevolent English men, Sheermaal pictures them as "Lazy Europeans" who are incapable of doing work for which they do slave trading. After describing "the cargo of slaves" full of " uncouth screams, their dismal groans, their countenances on which were alternatively depicted the images of fury, terror and despair" of black slaves under "the savage looks of the white barbarians"(Vol. I, p. 75), he disfavours the British people for their cruelty. He draws on the comparison between the slavery of England and bondsmen of Asia, especially during the Mogul regime. 
When I mention the slaves of Christians, let not your imagination turn to the bondsmen of Asia,as if their situation is parallel... But with these white savages, these merciless Christians, they are doomed to suffer all the cruelty, instigated by avarice and intoxicated by power, can inflict.(Vol. I, p. 77)

The use of words "savages", "merciless","avarice" and "intoxicated" all at a time exhibit the vices of the British people. Sheermaal notices their behaviour ruthless and cruel towards the traded soldiers. The description of English people as "benevolent" by Zaarmilla is just undercut by the ironical rendition of English people by Sheermaal. By exposing the bad aspects of British people, Shreemal valorises his own culture implicitly that sounds better than that one.

More than that, Sheermaal finds the women's condition bad in England. They are, for Sheermaal," rendering themselves objects of pleasure to the eyes of men" (Vol. I, p. 118). Their reduced status to the mistress annoys Sheermaal. They are "under the accumulated misery of want,disease and infamy" (Vol. I, p. 124). This upsets him. He finds the vanity in English culture which is mostly appropriated by Zaarmilla. Maandaara, the most faithful of friends of the powerful and enlightened Rajah, Zaarmilla, also pictures his negative impression of the Christian people. He mostly fears whether Zaarmilla changes his religion to Christianity.

When Zaarmilla finally writes his letter to Maandaara, he sums up all his experience as "all their virtues shall be the companion" and "their happiness shall solace every hour"(Vol. II, p. 290). In this way, he apprises his liking of the British cultures which does not go along with Sheermaal's perception.

Berry, concerning the psychological adaption, regards that it "largly involves one's psychological and physical well-being" (p. 709). If we put the case of Zaarmilla, it is psychological adaptation who does not pose extreme negative opinion like Sheermaal. In the level of socio-cultural adoption, for Berry, it "refers to how well an acculturating individual is able to manage daily life in the new cultural context" (p. 709). Zaarmilla, through his descriptions, sounds adoptive, even culturally and socially but when it comes the turn of Sheermaal, he rejects it. In the terms of Berry, he undergoes through acculturation stress. It is the situation "where individuals understand that they are facing problems resulting from intercultural contact that cannot be dealt with easily or quickly by 
simply adjusting or assimilating to them" (p. 708), Berry avers. Sheermaal's continuous rejection is because of the problem he has faced during the visit which created acculturation stress.

In conclusion, the ambivalent position of depiction of England and India by two Indian people do not take monolithic representation. It, hence, zeros the Saidian idea of biased negative representation of the East and positive representation of the West. The two oppositional explanations of the same manner of the same people leads the situation to the contradictory condition. To evaluate such two-way description of the European culture from two different eyes, the cultural acceptance and cultural stress are highlighted. In making connection with Saidian notion, this research comes to the conclusion that this novel equally raises the two contradictory voices leading to the condition of dual interpretation, an ambivalence. Hence, on the ground of acculturation and cultural stress, the novel is the amalgamation of both dimensions. Because of this inclusion, the novel becomes full of contradiction, making it ambivalent.

\section{Works Cited}

Barker, C. (2002). Making sense of cultural studies: Central problems and critical debates. Sage Publications. London.

Berry, J. W. (2005). "Acculturation: Living successfully in two cultures."International Journal of Intercultural Relations 29.6: 697-712.

Egeneolf, S. B. (1988). The art of political fiction in Hamilton, Edgeworth and Owenson. Ashgate Publishing Limited. Farnharm, England.

Hamilton, E. (1811). Translation of the letters of a Hindoo rajah: Written previous to, and during the period of his residence in England. To which is prefixed, a preliminary dissertation on the history, religion, and manners, of the Hindoos. Vol. 1,2. John Walker; Wilkie and Robinson; Longman, Hurst, Rees. Orme and Brown; R. Scholey; AK Newman and Company; and J. Johnson and Company.

Mellor, A. K. (Summer 2005). Studies in Romanticism "Romantic Orientalism Begins at Home: Elizabeth Hamilton's "Translations of the Letters of a Hindoo Rajah".44: 2, pp. 151-164. JSTOR, http://www.jstor.org/stable/25601725

Price, F. L. (2002). "Democratizing taste: Scottish common-sense philosophy and Elizabeth Hamilton." Romanticism 8.2: 179-196.

Pandey, B. (2009). "Pedagogy of Indian Partition literature in the Light of Trauma Theory." Southern Postcolonialisms: The Global South and the 'New' Literary 
Representations. Ed. Sumanyu Satpathy. London and New York: Routledge, 12438.

Said, E. W. (2003). Orientalism: Western conceptions of the Orient. Penguin Classics. London.

Sam, D. L. (2006). Acculturation: Conceptual background and core components. The Cambridge handbook of acculturation psychology, edited by David L. Sam and John W. Berry, Cambridge University Press, Cambridge, pp. 11-26. Cambridge Handbooks in Psychology.

Wallace, T. G. (1952). Imperial characters: Home and periphery in Eighteenth-Century literature. Lewisburg Bucknell University Press.Rosemont Publishing and Printing Corp., Cranbery, USA. 